\title{
Potential activities of Bacillus simplex as a biocontrol agent against root rot of Nigella sativa caused by Fusarium camptoceras
}

\author{
K. Mohamed Al-Sman ${ }^{1}$, Kamal Abo-Elyousr ${ }^{1,2^{*}}$ D, Amal Eraky ${ }^{1}$ and Aida El-Zawahry ${ }^{1}$
}

\begin{abstract}
This study aimed to investigate the impact of two isolates of Bacillus simplex (PHYB1 and PHYB9) for controlling the root rot disease of black cumin (Nigella sativa) caused by Fusarium camptoceras (PHYF1) under greenhouse and field conditions at Assiut Governorate, Egypt. The highest reduction percentage of infection (22.5\%) was recorded by the treatment of PHYB1 as suspension than the control (60\%). Both isolates of Bacillus spp. provided the root and foliar dry weight under greenhouse and seed production in the field. The results showed that the isolate PHYB1 as a formulation gave the highest impact in the root dry weight ( $0.28 \mathrm{~g} / \mathrm{plant})$, followed by PHYB9 $(0.22 \mathrm{~g} /$ plant), with insignificant difference between them. PHYB9 suspension also provided the highest seed production (27.97 g/plant), whereas PHYB9 as a formulation gave the lowest ( $24.08 \mathrm{~g} / \mathrm{plant})$. Studies on the interaction between Bacillus spp. on F. camptoceras by scanning electron microscope (SEM) revealed that both caused a complete mycoparasitism on the fungal growth. The bacterial growth was seen to adhere and colonize the hyphae, resulting in hyphal tissue maceration. Therefore, the use of both isolates of Bacillus spp. to control root rot disease of black cumin under greenhouse and field conditions can be recommended.
\end{abstract}

Keywords: Biological control, Black cumin, Bacillus spp., Fusarium wilt, Rhizobacteria

\section{Background}

Black cumin (Nigella sativa L., Family: Ranunculaceae) seeds have great economic importance as they occupy an export priority in the first rank. It has especial importance among the other traditional crops in the Middle and Upper Egypt, especially in Giza, Fayoum, BeniSuef, El-Minya, and Assiut Governorates (FAO 2016). It is an annual herb possessing a wide range of medicinal uses; the seeds are used in folk herbal medicine all over the world for the treatment and prevention of a number of diseases (Chevallier 1996). Root rot is one of the most serious diseases affecting black cumin. It is caused by Fusarium spp. (Sharma and Meena 2012). Fungal disease control is based mainly on the use of fungicides (Al-Sman et al. 2017). Fungicides may be toxic to animals, crops, and humans and

\footnotetext{
* Correspondence: kaaboelyousr@agr.au.edu.eg

${ }^{1}$ Plant Pathology Department, Faculty of Agriculture, Assiut University, Assiut 71526, Egypt

${ }^{2}$ Department of Arid Land Agriculture, Faculty of Meteorology, Environment and Arid Land Agriculture, King Abdulaziz University, Jeddah 80208, Saudi Arabia
}

could lead to the development of fungicide-tolerant pathogen strains (Abo-Elyousr et al. 2014). Biological control of soil-borne diseases, using bioagents, is an alternative method to the chemical control (AboElyousr et al. 2019). It offers a way to effectively control pathogens without harmful effects on animals, humans, plants, and/or the environment (Sallam et al. 2013). In recent years, various Bacillus spp. were used as potential biocontrol agents against different Fusarium spp. The use of plant growth-promoting rhizobacteria (PGPR) has become a common practice in many countries of the world (Abo-Elyousr and Mohammed 2009 and Alamri et al. 2019).

The objective of this study was to determine the effect of two Bacillus simplex isolates, PHY1 and PHYB9 isolates, to control the root rot disease of black cumin caused by Fusarium camptoceras (PHYF1) under greenhouse and field conditions in Assiut Governorate, Egypt. 


\section{Materials and methods}

\section{Source of microorganisms}

Pathogenic fungi isolate Fusarium camptoceras (PHYF1), the causal agent of root rot disease, was isolated from black cumin (Al-Sman et al. 2017). The isolate was grown in Petri dishes $(9 \mathrm{~cm}$ in diameter) which contained potato dextrose agar medium (PDA) (20 g dextrose, $15-20 \mathrm{~g}$ agar, $200 \mathrm{~g}$ potato, and $1 \mathrm{~L}$ water). Petri dishes were incubated for 7 days at $27^{\circ} \mathrm{C}$. Two isolates of Bacillus simplex (PHYB1 and PHYB9), isolated from the rhizosphere of black cumin, at Assiut Governorate, Egypt, were used. The isolates were identified according to their morphological and physiological characteristics (Dye 1968; Schaad 1988, and Holt et al. 1994).

\section{Inoculum preparation and soil infestation with the pathogenic fungi}

Inoculum of pathogenic isolate were prepared by inoculating of discs $0.5 \mathrm{~cm}$ in diameter of 5-day-old cultures of PHYF1 in bottles which contained the autoclaved barley medium (100 dried coarse sand, $75 \mathrm{~g}$ dried barley grains, $75 \mathrm{ml}$ tap water). Bottles were incubated for 15 days at $25 \pm 1{ }^{\circ} \mathrm{C}$ (Abo-Elyousr et al. 2009). After this period, the contents were mixed together and used as a source of inoculum. Pots $(30 \mathrm{~cm}$ diameter) filled with 5 $\mathrm{kg}$ soil were infested by mixing about $150 \mathrm{~g}$ of the inoculums with the soil and then irrigated directly. For control treatments, sterilized uninoculated soil were used (Gabr et al. 1998). Ten disinfested seeds of black cumin were seeded in each pot, 7 days after soil infestation with the pathogen (Hilal et al. 2000). Pots were irrigated directly after sowing and subsequently as needed for 8 weeks.

\section{Inoculum preparation of suspension antagonistic of Bacillus simplex}

The antagonistic bacterial isolates PHYB1 and PHYB9 were used in this study. Inoculum of each bacterial isolate was prepared by growing it in a nutrient yeast extract broth, incubated at $25^{\circ} \mathrm{C}$ on an orbital shaker at $200 \mathrm{rpm}$ for $24 \mathrm{~h}$. Bacteria were afterward polluted by centrifugation at $15,000 \mathrm{rpm}$ for $5 \mathrm{~min}$ and washed in distilled water and the concentration of the bacteria was adjusted to $10^{8} \mathrm{cfu}$.

\section{Preparation of formulation antagonistic Bacillus simplex}

To prepare the Bacillus spp. formulation, the method of Abo-Elyousr and El-Hendawy (2008) was followed. In brief, each isolate was grown separately at $20^{\circ} \mathrm{C}$ in 250 $\mathrm{ml}$ flask each containing $100 \mathrm{ml}$ of tryptic soya broth liquid medium and shaking at $1000 \mathrm{rpm}$ for $48 \mathrm{~h}$. A $400-$ $\mathrm{ml}$ aliquot of the bacterial suspension containing $\left(10^{8}\right.$ $\mathrm{cfu} \mathrm{ml}^{-1}$ ) was mixed by $1 \mathrm{~kg}$ of the talc powder (dry-sterilized at $105^{\circ} \mathrm{C}$ for $12 \mathrm{~h}$ ), $15 \mathrm{~g} \mathrm{CaCO}_{3}$ (to adjust the $\mathrm{pH}$ to 7 ), and $10 \mathrm{~g}$ carboxymethylcellulose.
Effect of Bacillus simplex as suspension/or formulation on disease severity under greenhouse conditions

Inoculums and pot infestation of the tested pathogenic isolate PHYF1 were prepared as previously mentioned. Each pot was planted by ten sterilized seeds of black cumin after they were soaked in the antagonistic bacterial suspension for $20 \mathrm{~min}$ and was also treated with the formulation bacteria; they were left to dry then grown directly. Two controls were used in this experiment: one was healthy control (untreated with bioagents or pathogens) and the second was infected control (untreated with bioagents but infected with the pathogen). The treatments were arranged in a randomized complete block design with five replicates. Results were recorded as disease severity percentage after 80 days of planting. The root rot was scored on $0-3$ scale, where:

0 = healthy, creamy white on discoloration of sub crown internode and crown roots, 1 = light brown discoloration of sub crown internode and crown roots, $2=$ brown discoloration of sub crown internode and crown roots, and 3 = dark brown to black discoloration of sub crown internode and crown roots and/or roots mostly decayed (Tinline et al. 1975). The disease severity (disease index) was estimated according to the following equation (Seleim et al. 2011):

$$
\text { Root rot index }=\frac{(n \times 1)+(n \times 2)+(n \times 3)}{T \times 3} \times 100 \text {. }
$$

$n=$ number of plants in each scale of disease plants (1, 2, 3)

$T=$ total number of plants

At the end of the experiment, plants from various treatments were removed, washed thoroughly with running water, then oven dried at $65^{\circ} \mathrm{C}$ for $72 \mathrm{~h}$ for dry weight. The experiment was repeated twice.

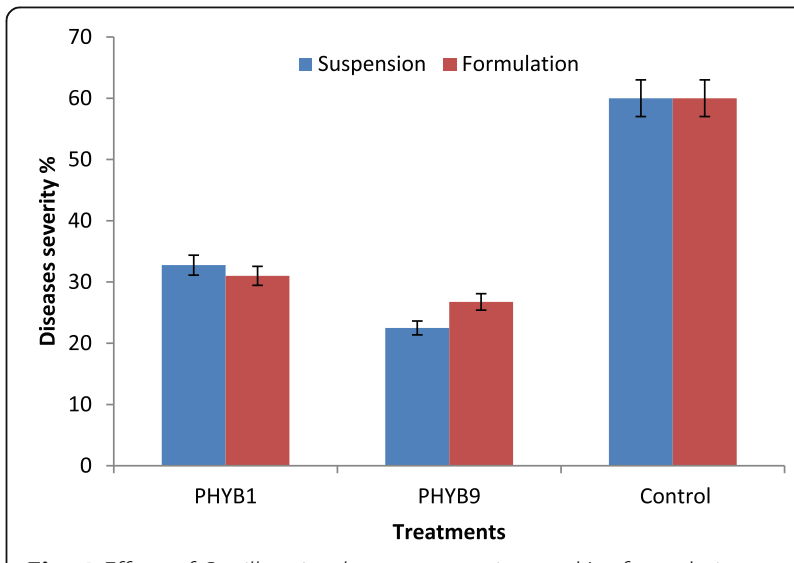

Fig. 1 Effect of Bacillus simplex as suspension and/or formulation on disease severity under greenhouse conditions. Error bars indicate the standard division 
Table 1 Effect of Bacillus simplex as suspension and/or formulation on root and foliar dry weight under greenhouse conditions

\begin{tabular}{|c|c|c|c|c|c|c|}
\hline \multirow[t]{2}{*}{ Treatments } & \multicolumn{3}{|c|}{ Root dry weight (gm/plants) } & \multicolumn{3}{|c|}{ Foliar dry weight (gm/plants) } \\
\hline & Suspension & Formulation & Mean of treatments & Suspension & Formulation & Mean of treatments \\
\hline PHYB1 & $0.29 \mathrm{ab}$ & $0.28 \mathrm{abc}$ & $0.28 \mathrm{a}$ & $2.11 \mathrm{~b}$ & $2.46 \mathrm{a}$ & $2.02 \mathrm{a}$ \\
\hline PHYB9 & $0.21 \mathrm{c}$ & $0.22 b c$ & $0.21 \mathrm{~b}$ & $1.76 \mathrm{c}$ & $2.45 a$ & $1.72 b$ \\
\hline Infected control & $0.08 d$ & $0.10 d$ & $0.09 \mathrm{c}$ & $0.72 \mathrm{~d}$ & $0.75 d$ & $0.73 c$ \\
\hline Healthy control & $0.30 \mathrm{a}$ & $0.30 \mathrm{a}$ & $0.30 \mathrm{a}$ & $2.46 \mathrm{a}$ & $2.42 \mathrm{a}$ & $2.44 \mathrm{a}$ \\
\hline Mean & $0.22 \mathrm{a}$ & $0.22 \mathrm{a}$ & & $1.73 \mathrm{a}$ & $1.80 \mathrm{a}$ & \\
\hline
\end{tabular}

Values in the column followed by a similar letter are not significantly different as determined by the LSD test $(P=0.05)$

\section{Control of the disease using Bacillus simplex under field conditions}

The field trials were conducted at the Experimental Farm of Plant Pathology Department, Faculty of Agriculture, Assiut University, Egypt, during 2014/2015 and 2015/2016 growing seasons. The plots were divided into two rows: length/row $2 \mathrm{~m}$ and five holes/ row; three plots were used for each treatment. The distance between holes is $30 \mathrm{~cm}$ and the infestation was carried out by adding $10 \mathrm{~g}$ substrate containing inocula of the pathogen PHYF1. Seeds were treated by bioagents as in greenhouse experiment. Disease severity percentage was recorded after 80 days from planting, and seed production (g/plants) was recorded at the end of experiment.

\section{Scanning electron microscopic (SEM) examination and photography}

The method of Zhou et al. (2011) for preparing the samples was followed. After growing the bacterial suspensions of PHYB1 and PHYB9 with the pathogen PHYF1 in Petri dishes, 2-3 samples, size 3-5 $\mathrm{mm}$, from the direct interactions were cut and fixed in 5\% cold buffered glutaraldehyde for $2 \mathrm{~min}$. The samples were scanned at $15 \mathrm{kV}$, using a JEOL JSM $5300 \mathrm{Lv}$ scanning electron microscope, and photographed.

\section{Evaluation of fixed and volatile oils Distillery fixed oils}

Soxhlet extractor was used to get fixed oils of black cumin seeds, according to Salea et al. (2013).

\section{Distillery volatile oils}

Clevenger type device was used to get an oil pilot from black cumin seeds. In this method, steam was passed through the seeds containing the volatile oils; $100 \mathrm{~g}$ of the seeds were placed in flasks with $500 \mathrm{ml}$ water and left for $3 \mathrm{~h}$ for the seeds boiling. The water evaporated carrying the volatile oil and dried over anhydrous sodium sulphate (Khalid and Shedeed 2016).

\section{Statistical analysis}

Analyses of variance were carried out, using MSTAT-C program version 2.10 (1991) and least significant difference (LSD) at $P \leq 0.05$ was employed to test significant difference between treatments (Gomez and Gomez 1984). All experiments were performed twice.

\section{Results and discussion \\ Effect of $B$. simplex on disease severity under greenhouse conditions}

The two isolates significantly reduced the disease severity than the control when treated as suspension or formulation. Isolate PHYB9 was more effective to the disease severity than PHYB1 (22.5 and 32.75\%, respectively, Fig. 1). There was an insignificant difference between the two methods of application, suspension or formulation. Biocontrol of plant diseases usually involve interactions between the host, pathogen, and antagonist. Bacillus sp. is one of the important biocontrol agents that are potentially useful for biological control of plant diseases due to ability to form endospores and produce different biologically active compounds with a broad host range and a broad spectrum of activity (Chen et al.

Table 2 Effect of Bacillus simplex as suspension and/or formulation on disease severity under field conditions in 2015 and 2016 growing seasons

\begin{tabular}{|c|c|c|c|c|c|c|}
\hline \multirow[t]{2}{*}{ Treatments } & \multicolumn{3}{|c|}{ Disease severity percentage in field 2015} & \multicolumn{3}{|c|}{ Disease severity percentage in field 2016} \\
\hline & Suspension & Formulation & Mean of treatments & Suspension & Formulation & Mean of treatments \\
\hline PHYB1 & $26.13 \mathrm{C}$ & $11.13 f$ & $18.63 b$ & $13.75 \mathrm{~b}$ & $14.75 \mathrm{~b}$ & $14.25 \mathrm{~b}$ \\
\hline PHYB9 & $25.63 \mathrm{C}$ & 14.38 ef & $20.00 \mathrm{~b}$ & $8.75 \mathrm{bc}$ & $10.00 \mathrm{bc}$ & $9.37 \mathrm{~b}$ \\
\hline Infected control & $58.13 \mathrm{a}$ & 39.38 b & $48.75 \mathrm{a}$ & 49.38 a & 49.38 a & $49.38 \mathrm{a}$ \\
\hline Mean & $26.73 \mathrm{a}$ & $16.83 \mathrm{~b}$ & & $17.97 \mathrm{a}$ & 18.53 a & \\
\hline
\end{tabular}

Values in the column followed by a similar letter are not significantly different as determined by the LSD test $(P=0.05)$ 
Table 3 Effect of Bacillus simplex as suspension and/or formulation on seed production under field conditions in 2015 and 2016 growing seasons

\begin{tabular}{|c|c|c|c|c|c|c|}
\hline \multirow[t]{2}{*}{ Treatments } & \multicolumn{3}{|c|}{ Seed production 2015} & \multicolumn{3}{|c|}{ Seed production 2016} \\
\hline & Suspension & Formulation & Mean of treatments & Suspension & Formulation & Mean of treatments \\
\hline PHYB1 & $26.30 \mathrm{~b}$ & $26.42 b$ & $18.63 b$ & $24.83 \mathrm{a}$ & $31.42 \mathrm{a}$ & $28.13 \mathrm{a}$ \\
\hline PHYB9 & $27.97 b$ & $24.08 \mathrm{~b}$ & $20.00 \mathrm{~b}$ & 31.45 a & $28.40 \mathrm{a}$ & 29.92 a \\
\hline Infected control & $8.80 \mathrm{c}$ & $8.80 \mathrm{c}$ & $48.75 a$ & $10.18 b$ & $10.18 b$ & $10.18 b$ \\
\hline Healthy control & 39.70a & 39.70 a & $39.7 \mathrm{~b}$ & 34.20 a & $34.20 \mathrm{a}$ & $34.20 \mathrm{a}$ \\
\hline Mean & $25.70 \mathrm{a}$ & $24.75 \mathrm{a}$ & & $25.16 \mathrm{a}$ & $26.05 \mathrm{a}$ & \\
\hline
\end{tabular}

Values in the column followed by a similar letter are not significantly different as determined by the LSD test $(P=0.05)$

2013 and Fira et al. 2018). They screened 60 isolates isolated from China, and 6 strains from these isolates exhibited above $50 \%$ biocontrol efficacy on tomato wilt caused by Ralstonia solanacearum under greenhouse conditions. It is plant growth-promoting rhizobacteria that can have beneficial effects on plant growth (Gamez et al. 2019). The use of Bacillus against Fusarium wilt in different plant species including horticultural crops has been widely documented (Hashem and Abo-Elyousr 2011 and Alamri et al. 2019).

\section{Effect of $B$. simplex on dry weight of root and foliar dry weight under greenhouse conditions}

The data presented in Table 1 showed that seeds treated with PHYB1 and PHYB9 as a suspension or a formulation increased the root dry weight. PHYB1 gave the highest effect in the dry weigh $(0.29 \mathrm{~g} /$ plant $)$ than that by PHYB9 $(0.21 \mathrm{~g} /$ plant $)$ and then the control $(0.08 \mathrm{~g} /$ plant $)$. The results showed that bacteria PHYB1, as a formulation gave the highest effect on the root dry weight $(0.28 \mathrm{~g} /$ plant $)$, followed by PHYB9 with insignificant difference between them. Also, applications of PHYB1 and PHYB9 as a suspension and formulation gave the best foliar dry weight (2.11 and $1.76 \mathrm{~g} /$ plant), with insignificant difference between PHYB1 and PHYB9 when used as a formulation

Also, obtained results reported herein showed that bacterial suspension (PGPR) had the greatest efficacy regarding the morphological parameters of the seeds. Principally, the two treatments (formulation and suspension) were not different in most of the main studied traits of

Table 4 Effect of Bacillus simplex as suspension and/or formulation on volatile oils and fixed oils

\begin{tabular}{|c|c|c|c|c|}
\hline \multirow[t]{2}{*}{ Treatments } & \multicolumn{2}{|c|}{ Volatile oils $(100 \mathrm{gm})$ seeds } & \multicolumn{2}{|c|}{ Fixed oils (100) gm seeds } \\
\hline & Suspension & Formulation & Suspension & Formulation \\
\hline PHYB1 & $0.34 \mathrm{~b}$ & $0.27 \mathrm{~b}$ & $0.7 \mathrm{~b}$ & $0.4 \mathrm{c}$ \\
\hline PHYB9 & $0.32 \mathrm{c}$ & $0.22 \mathrm{c}$ & $0.6 \mathrm{c}$ & $0.9 \mathrm{~b}$ \\
\hline Infected control & $0.16 d$ & $0.13 d$ & $0.4 \mathrm{~d}$ & $0.4 \mathrm{c}$ \\
\hline Healthy control & $0.38 \mathrm{a}$ & $0.37 \mathrm{a}$ & $1.0 \mathrm{a}$ & $1.0 \mathrm{a}$ \\
\hline
\end{tabular}

Values in the column followed by a similar letter are not significantly different as determined by the LSD test $(P=0.05)$ plant growth. The results agree with previous studies of Miao et al. (2018). Biocontrol agents enhanced the plant growth by production of phytohormones, which are usually believed to be involved in plant growth promotion (Glickmann and Dessaux 1995). Gopalakrishnan et al. (2012) stated that the PGPR enhanced the morphological parameters of the plant by their production of some hormone, such as indole acetic acid (IAA), siderophore production, and phosphate solubilization. IAAproducing microorganisms are known to promote root elongation and plant growth

\section{Effect of $B$. simplex on disease severity and seed production under field conditions Disease severity percentage}

Both tested bacterium isolates were effective against disease severity of black cumin in field when treated as a suspension. PHYB1 and PHYB9 gave highest reduction of disease severity (26.13 and $25.63 \%$, respectively) than the control (58.13\%). Treatment with PHYB1 as a formulation gave the highest reduction of disease severity (11.13\%) than PHYB9 (14.84\%) (Table 2). Also, in the 2016 season, the results indicated that both bacterial isolates were effective on disease severity when treated as suspension or formulation, with insignificant difference between them. PHYB9 as a suspension gave the best reduction of disease severity (8.75\%), while PHYB1 as a formulation gave lower effect (14.75\%) (Table 2). Under greenhouse or field experiments, both bacteria significantly decreased the disease severity percentage than the untreated control. Obtained results are in harmony with those reported by Sallam et al. (2013). The results showed that both treatments increased seed yield and plant growth in terms of root and steam dry weight. Many researchers demonstrated that PGPR significantly increased the yield and yield components (Yadegari and Rahmani 2010; Ekinci et al. 2014).

\section{Seed production}

Seeds treated with both isolates PHYB1 and PHYB9 as a suspension or formulation improved its production. 


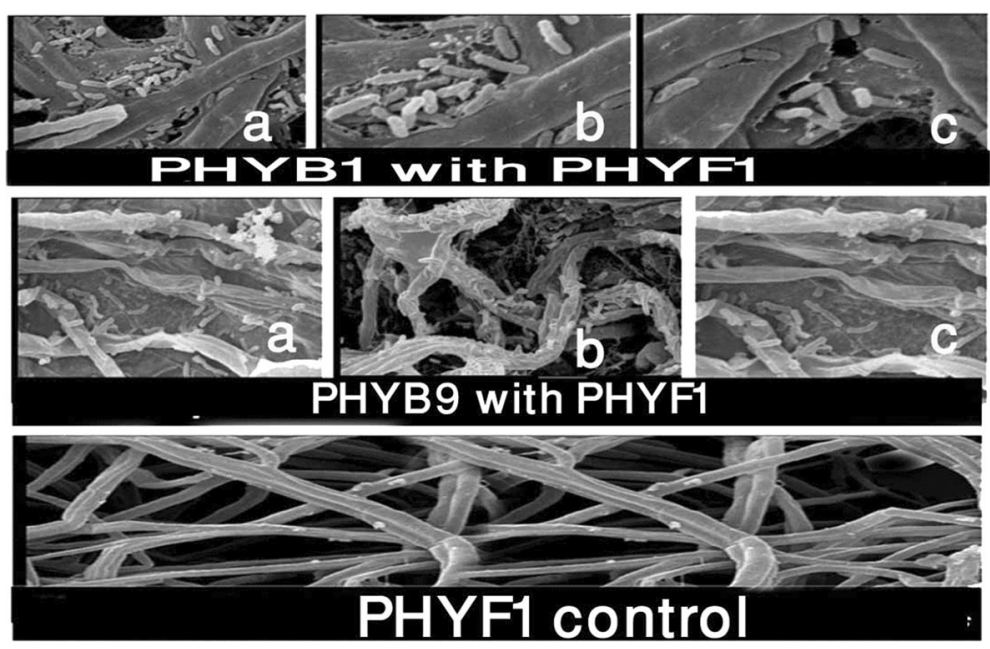

Fig. 2 Interaction between Bacillus simplex strain (PHYB1 and BHYB9 with mycelia of F. camptoceras (PHYF1). Electron microscopic scanning photographs

PHYB1, as a suspension, gave the higher seed production $(27.97 \mathrm{~g} /$ plants) than PHYB9 as a formulation $(24.08 \mathrm{~g} /$ plants $)$ with insignificant difference between them (Table 3).

\section{Effect of B. simplex on volatile oils and fixed oils}

Seeds of black cumin infected with $F$. camptoceras and treated with PHYB1 as a suspension gave a higher amount of volatile oil $(0.34 \mathrm{mg} / 100 \mathrm{~g}$ seeds $)$ than the PHYB9 and the less amount recorded by PHYB9 as formulation $(0.22 \mathrm{mg} / 100 \mathrm{~g}$ seeds) and then the control $(0.13 \mathrm{mg} / 100 \mathrm{~g}$ seeds) (Table 4$)$. Also, the data show that PHYB9, as a formulation, gave the highest rate of fixed oil $(0.9 \mathrm{mg} / 100 \mathrm{~g}$ seeds) and PHYB9, as a suspension, gave $0.7 \mathrm{mg} / 100 \mathrm{~g}$ seeds.

\section{Interaction between $B$. simplex strain and mycelia of $F$. camptoceras}

The studies revealed the nature of antagonism involved in the interaction between the isolated PHYB1 and PHYB9 with F. camptoceras. A clear distortion of fungal mycelium following lysis and bursting of the hyphae was observed at the interaction zone in dual cultures. The burst sites were surrounded by bacteria, some of which were found attached to the hyphae (Fig. 2b). Ultrastructural studies scanning electron microscope showed that this bioagents' mode of action against $F$. camptoceras includes two types of antagonism, antibiosis, and parasitism. Loss of pathogen hyphae structural integrity and reduction in spores developed due to antibiosis of strain were observed. Further, hyperparasitism of PGPR on fungal hyphae was evident through maceration, lysis of hyphal filaments, shriveling, shrinking, and abnormal coiling (Fig. 2a). These results are consistent with Lim et al. (1991). Antagonistic effect could be due to direct influence of bioagents against pathogens. The interaction between $B$. simplex on F. camptoceras revealed that the Bacillus caused a complete mycoparasitism on the fungal growth. The bacterial growth was seen colonizing the hyphae and adhering, thus leading to maceration of hyphal tissues or antagonistic effect may be due to direct effect of antagonistic bacteria against $F$. camptoceras through cloning their hyphae to prevent their continued growth (Patel and Saraf 2017).

\section{Conclusion}

The plant growth-promoting rhizobacteria (PGPR) $B$. simplex PHYB 1 and 9 proved significant reductions of disease severity of $F$. camptoceras (PHYF1), when used as a suspension or formulation. They also improved the vegetative growth and seed productivity and quantity of fixed and volatile oils in black cumin.

\section{Acknowledgements}

Not applicable

\section{Authors' contributions}

All authors contributed equally in the manuscript. AKM participated in the planning and implementation of the experiments, sampling, lab work, writing of the draft, and writing of the manuscript. AMK participated in the bacterial identification, implementation of the experiments, and writing of the manuscript. AE participated in the planning and implementation of the experiments, analyzing of data, and writing of the draft. AE participated in the implementation of the experiments and collection of data. All authors read and approved the final manuscript.

\section{Funding}

Not applicable

Availability of data and materials Not applicable

Ethics approval and consent to participate

This manuscript is in accordance with the guide for authors available on the journal's website. Also, this work has not been published previously and is approved by all authors and host authorities 


\section{Consent for publication}

All authors approve to publication

\section{Competing interests}

The authors declare that they have no competing interests.

Received: 31 July 2019 Accepted: 12 November 2019

Published online: 02 December 2019

\section{References}

Abo-Elyousr KAM, Bagy HMM, Hashem M, AMA S, Mostafa YS (2019) Biological control of tomato wilt caused by Clavibacter michiganensis subsp. michiganensis using formulated plant growth-promoting bacteria. Egypt J Biol Pest Cont 29:54. https://doi.org/10.1186/s41938-019-0152-6

Abo-Elyousr KAM, El-Hendawy HH (2008) Integration of Pseudomonas fluorescens and acibenzolar-S-methyl to control bacterial spot disease of tomato. Crop Protect. 27:1118-1124

Abo-Elyousr KAM, Hashem M, Ali E (2009) Integrated control of cotton root rot disease by mixing fungal biocontrol agents and resistance inducers. Crop Protect. 28:295-301

Abo-Elyousr KAM, Mohammed H (2009) Biological control of fusarium wilt in tomato by plant growth-promoting yeasts and rhizobacteria. Plant Pathol. J. 25:199-204

Abo-Elyousr KAM, Seleim MAA, Abd-El-Moneem KMH, Saead FA (2014) Integrated effect of Glomus mosseae and selected plant oils on control of tomato bacterial wilt. Crop Protect. 66:67-71

Alamri SAM, Moustafa MHYS, Nafady NA, Abo-Elyousr KAM (2019) Biological control of root rot in lettuce caused by Exserohilum rostratum and Fusarium oxysporum via induction of the defense mechanism. Boil Cont. 128:76-84

Al-Sman KM, KAM A-E, Amal E, Aida E-Z (2017) Isolation, identification and biomanagement of root rot of black cumin (Nigella sativa) using selected bacterial antagonists. Int J Phytopathol 06(03):47-56

Chen Y, Yan F, Chai Y, Liu H, Kolter R, Losick R (2013) Biocontrol of tomato wilt disease by Bacillus subtilis isolates from natural environments depends on conserved genes mediating biofilm formation. Environ Microbiol 15(3):848864

Chevallier A (1996) The Encyclopedia of Medicinal Plants. Dorling Kindersley Book, London, ISBN-(13), p 227

Dye DW (1968) Taxonomic study of the genus Erwinia. I. The "amylovora" group. New Zealand J Scien 11:590-607

Ekinci M, Turan M, Yildirim E, Güneş A, Kotan R, Dursun A (2014) Effect of plant growth promoting rhizobacteria on growth, nutrient, organic acid, amino acid and hormone content of cauliflower (Brassica Oleracea L. var. Botrytis) transplants. Acta Sci Pol Hortorum Cultus 13(6):71-85

Fira D, Dimkic I, Beric T, Lozo J, Stankovic S (2018) Biological control of plant pathogens by Bacillus species. J Biotechnol 10(285):44-55

Food and Agriculture Organization of United Nation (FAO), FAOSTAT, Crops, 2016, available at http://fenix.fao.org/faostat/beta/en/\#data/OC

Gabr MR, Saleh OI, Hussein NA, Khalil MA (1998) Physiological studies and cellwall degrading enzymes of Fusarium oxysporum $f$. sp. sesami and Macrophonmina phaseolina, the causal diseases of sesame. Egyptian J Microbiol 33:595-610

Gamez RM, Cardinale M, Montes S, Ramirez SS, Chnell F (2019) Screening, plant growth promotion and root colonization pattern of two rhizobacteria (Pseudomonas fluorescens Ps006 and Bacillus amyloliquefaciens Bs006) on banana cv. Williams (Musa acuminata Colla) 220:12-20

Glickmann E, Dessaux Y (1995) A critical examination of the specificity of the Salkowski reagent for indoleic compounds produced by phytopathogenic bacteria. Appl Environ Microbiol 61:793-796

Gomez KA, Gomez AA (1984) Statistical procedures for agriculture research. Inter Sinence Publication, New York, p 678

Gopalakrishnan S, Upadhyaya H, Vadlamudi S, Humayun P, Vidya MS, Alekhya G, Singh A, Vijayabharathi R, Ratna KB, Murali SR, Rupela AO (2012) Plant growth - promoting traits of biocontrol potential bacteria isolated from rice rhizosphere. PMC 1(1):71

Hilal AA, Abdelel-Mageed MH, Nawal AE, Ibrahim AIM (2000) Root rot wilt of three cut flower plants in Egypt. Ann Agric Scienc Mashtohor 38:2183-2197

Holt G, John D, Bergey H (1994) Bergey's manual of determination bacteriology. Eds Williams and Wilkinc, Baltimore, Maryland, p 787

Khalid AK, Shedeed MR (2016) GC-MS analyses of black cumin essential oil produces with sodium chloride. Inter Food Res J 23(2):832-836
Lim HS, Kim YS, Kim SD (1991) Pseudomonas stutzeri YPL-1 genetic transformation and antifungal mechanism against Fusarium solani, an agent of plant root rot. Appl Envir Microbiol. 57(2):510

Miao G-p, Han J, Wang C-r, Zhang K-g, Wang S (2018) Growth inhibition and induction of systemic resistance against Pythium aphanidermatum by Bacillus simplex strain HS-2. Bio Scien Technol 28(12):1114-1127

Hashem H, Abo-Elyousr KAM (2011) Management of the root-knot nematode Meloidogyne incognita on tomato with combinations of different biocontrol organisms. Crop Protect 30:285-292

MSTAT-C (1991) A software program for the design, management and analysis of agronomic research experiments. Michigan State University, p 400

Patel S, Saraf M (2017) Interaction of root colonizing biocontrol agents demonstrates the antagonistic effect against Fusarium oxysporum f. sp. lycopersici on tomato. Euro J Plant Pathol 149(2):425-433

Salea R, Widjojokusumo E, Hartanti AW, Veriansyah B, Tjandrawinata R (2013) Supercritical fluid carbon dioxide extraction of Nigella sativa (black cumin) seeds using taguchi method and full factorial design. Herbert open Access journals

Sallam NA, Riad Shaimaa N, Mohamed SM, El-eslam AS (2013) Formulations of Bacillus spp. and Pseudomonas fluorescensfor biocontrol of cantaloupe root rot caused by Fusarium solani. J Plant Protect Res. 53(3):295-300

Schaad NW (1988) Identification schemes. In: Schaad NW (ed) Laboratory guide of identification of plant pathogenic bacteria, 2nd edn. Press, St. Paul, Minn, pp 1-15

Seleim MAA, Saead FA, Abd-El-Moneem KMH, Abo-Elyousr KAM (2011) Biological control of bacterial wilt of tomato by plant growth promoting rhizobacteria. Plant Pathol J 10(4):146-153

Sharma YK, Meena SS (2012) Effect of planting time and plant spacing on root rot of Nigella sativa. Inter J Seed spices 2(1):77-78

Tinline RD, Ledingham RJ, Sallans BJ (1975) Appraisal of loss from common root in wheat. In: Bruehl GW (ed) Biology and Control of Soil-borne Plant Pathogens, pp 22-26

Yadegari M, Rahmani H (2010) The effect of evaluation of bean seeds inoculation with Rhizobium phaseoli and plant growth promoting rhizobacteria (PGPR) on yield and yield components. Afr J Agric Rese 5:792-799

Zhou X, Lu Z, Lv F, Zhao H, Wang Y (2011) Antagonistic action of Bacillus subtilis strain fmbj on the postharvest pathogen Rhizopus stolonifer. J Food Scien 76: $254-259$

\section{Publisher's Note}

Springer Nature remains neutral with regard to jurisdictional claims in published maps and institutional affiliations.

\section{Submit your manuscript to a SpringerOpen ${ }^{\circ}$ journal and benefit from:}

- Convenient online submission

- Rigorous peer review

- Open access: articles freely available online

- High visibility within the field

- Retaining the copyright to your article

Submit your next manuscript at $\boldsymbol{\nabla}$ springeropen.com 